\title{
TANK 40 FINAL SB4 CHEMICAL CHARACTERIZATION RESULTS
}

C. J. Bannochie

January 2008

Process Science \& Engineering Section Savannah River National Laboratory Aiken, SC 29808

Prepared for the U.S. Department of Energy Under Contract Number DEAC09-96SR18500

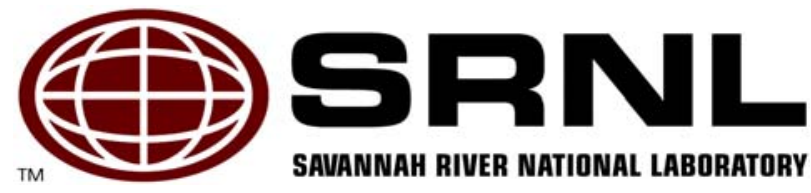




\section{DISCLAIMER}

This report was prepared by Westinghouse Savannah River Company (WSRC) for the United States Department of Energy under Contract No. DE-AC09-96SR18500 and is an account of work performed under that contract. Neither the United States Department of Energy, nor WSRC, nor any of their employees makes any warranty, expressed or implied, or assumes any legal liability or responsibility for the accuracy, completeness, or usefulness, of any information, apparatus, or product or process disclosed herein or represents that its use will not infringe privately owned rights. Reference herein to any specific commercial product, process, or service by trademark, name, and manufacturer or otherwise does not necessarily constitute or imply endorsement, recommendation, or favoring of same by WSRC or by the United States Government or any agency thereof. The views and opinions of the authors expressed herein do not necessarily state or reflect those of the United States Government or any agency thereof.

\section{Printed in the United States of America \\ Prepared For U.S. Department of Energy}




\section{TANK 40 FINAL SB4 CHEMICAL CHARACTERIZATION RESULTS}

C. J. Bannochie

January 2008

Process Science \& Engineering Section Savannah River National Laboratory

Aiken, SC 29808

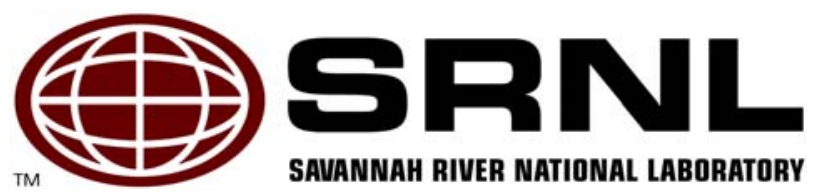




\section{AUTHOR(S):}

C. J. Bannochie, Process Science \& Engineering Section

Date

\section{TECHNICAL REVIEWERS:}

D. C. Koopman, Process Science \& Engineering Section

Date

N. E. Bibler, Process Science \& Engineering Section

Date

\section{APPROVERS}

R. E. Edwards, Jr., Manager, Process Science \& Engineering Section

Date

C. C. Herman, Manager, Process Engineering \& Technology

Date

J. E. Occhipinti, Manager, DWPF Process Engineering

Date 


\section{EXECUTIVE SUMMARY}

A sample of Sludge Batch 4 (SB4) was pulled from Tank 40 in order to obtain radionuclide inventory analyses necessary for compliance with the Waste Acceptance Product Specifications (WAPS) ${ }^{1}$. This sample was also analyzed for elemental and chemical composition including noble metals. These analyses along with the WAPS analyses will help define the composition of the sludge currently in Tank 40 which is currently being fed to DWPF and will become part of Sludge Batch 5 (SB5).

At SRNL the 3-L Tank 40 SB4 sample was transferred from the shipping container into a 4-L vessel and solids allowed to settle overnight. Supernate was then siphoned off and circulated through the shipping container to complete the transfer of the sample. Following thorough mixing of the 3-L sample, a $280 \mathrm{~g}$ sub-sample was removed. This sub-sample was then utilized for all subsequent analytical samples.

Eight separate aliquots of the slurry were digested, four with $\mathrm{HNO}_{3} / \mathrm{HCl}$ in sealed Teflon ${ }^{\circledR}$ vessels and four in $\mathrm{Na}_{2} \mathrm{O}_{2}$ using $\mathrm{Zr}$ crucibles. Due to the use of $\mathrm{Zr}$ crucibles and $\mathrm{Na}$ in the peroxide fusions, Na and $\mathrm{Zr}$ cannot be determined from this preparation. Three glass standards were digested along with a blank for each preparation. Each aqua regia digestion and blank was diluted and submitted to Analytical Development (AD) for inductively coupled plasma - atomic emission spectroscopy (ICP-AES) analysis, inductively coupled plasma - mass spectrometry (ICP-MS) analysis, and cold vapor atomic absorption (CV-AA) analysis. Equivalent dilutions of the peroxide fusion digestions and blank were submitted to $\mathrm{AD}$ for ICP-AES analysis.

Tank 40 SB4 supernate was collected from a mixed slurry sample in the SRNL Shielded Cells and submitted to AD for ICP-AES and ICP-MS. Weighted dilutions of slurry were submitted for ion chromatography (IC), total inorganic carbon/total organic carbon (TIC/TOC), and total base analyses.

A sample of Tank 40 SB4 decant was collected by carefully removing the supernate phase from a settled sample. This decant was not filtered prior to performing a warm nitric acid digestion of the material in order to measure the Si content by ICP-AES. Three Si standards, a blank, and a matrix standard were prepared and submitted along with the Tank 40 samples.

The following conclusions were drawn from the analytical results reported here:

- The elemental composition of this sample and the analyses conducted here are reasonable and consistent with DWPF batch data measurements.

- There was no measurable Si in samples of Tank 40 decant.

- $\quad$ Ag and the $\mathrm{Ru}, \mathrm{Rh}$, and Pd noble metal concentrations agree well with the estimate used for the SB4 70/30 blend of SB3 and Tank 51 performed in the SRNL Shielded Cells.

\footnotetext{
${ }^{1}$ Office of Environmental Restoration and Waste Management, Waste Acceptance Product Specifications for Vitrified High-Level Waste Forms, US DOE Document DOE/EM-0093, Rev. 2, (12/96).
} 


\section{TABLE OF CONTENTS}

EXECUTIVE SUMMARY

iii

LIST OF TABLES

LIST OF ACRONYMS/ABBREVIATIONS

1.0 INTRODUCTION AND BACKGROUND

2.0 APPROACH AND RESULTS

2.1 Analytical Methods

2.2 Results

3.0 DISCUSSION

3.1 Carbonate

3.2 Warm Acid Strike for Soluble Silica

3.3 Sulfur

11

3.4 Elemental Ratios

11

3.5 Noble Metal Ratios

11

4.0 CONCLUSIONS

12

5.0 REFERENCES

13

6.0 ACKNOWLEDGEMENTS 


\section{LIST OF TABLES}

Table 2-1. Weight Percent Solids and Density for Tank 40 SB4 Samples and DWPF SRAT Receipt Batch 416 [Number of Samples Included in Average]....

Table 2-2. Supernate Analyses for Tank 40 SB4 Samples [Number of Samples Included in Average] (Molar or moles/L supernate)

Table 2-3. Elemental Composition of Tank 40 SB4 Decant Samples [Number of Samples Included in Average] (Molar or moles/L supernate) ...................................................... 6

Table 2-4. Carbon Analysis for Tank 40 SB4 Samples [Number of Samples Included in

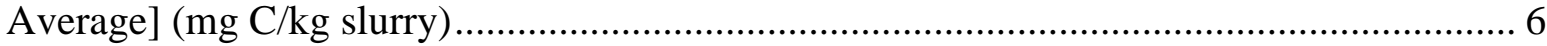

Table 2-5. Base Analysis for Tank 40 SB4 Samples [Number of Samples Included in Average] (mol/kg slurry)

Table 2-6. Elemental Concentrations in Tank 40 SB4 Samples in Wt \% of Total Solids [Number of Samples Included in Average] (Std. Dev., \%RSD) .................................................... 8

Table 2-7. Noble Metal Fission Products and Silver Concentrations in Tank 40 SB4 WAPS and Qualification Samples in Wt \% of Total Solids 9

Table 3-1. Comparison of Elemental Ratios of Major Insoluble Elements in Tank 40 SB4 Sample with DWPF Batch 416 SRAT Product Data....................................................... 11

Table 3-2. Fission Yield Ratios and Measured Noble Metal Ratios in Various SB4 Samples ... 12 


\section{LIST OF ACRONYMS/ABBREVIATIONS}

$\begin{array}{ll}\text { AD } & \text { Analytical Development } \\ \text { ARG }-1 & \text { Analytical Reference Glass - 1 } \\ \text { ASP } & \text { Analytical Study Plan } \\ \text { CV-AA } & \text { Cold Vapor - Atomic Absorption Spectroscopy } \\ \text { DWPF } & \text { Defense Waste Processing Facility } \\ \text { IC } & \text { Ion Chromatography } \\ \text { ICP-AES } & \text { Inductively Coupled Plasma - Atomic Emission Spectroscopy } \\ \text { ICP-MS } & \text { Inductively Coupled Plasma - Mass Spectrometry } \\ \text { L } & \text { Liter } \\ \text { M } & \text { Molar } \\ \text { NA } & \text { Not Available (e.g. Not Measured) } \\ \text { RSD } & \text { Relative Standard Deviation } \\ \text { SB4 } & \text { Sludge Batch 4 } \\ \text { SC-1 } & \text { Shielded Cells SRAT/SME Run 1 } \\ \text { SRNL } & \text { Savannah River National Laboratory } \\ \text { Std. Dev. } & \text { Standard Deviation } \\ \text { TC } & \text { Total Carbon } \\ \text { TIC } & \text { Total Inorganic Carbon } \\ \text { WAPS } & \text { Waste Acceptance Product Specifications } \\ \text { Wt \% } & \text { Weight Percent }\end{array}$




\subsection{INTRODUCTION AND BACKGROUND}

A sample of Sludge Batch 4 (SB4) was pulled from Tank 40 in order to obtain radionuclide inventory analyses necessary for compliance with the Waste Acceptance Product Specifications (WAPS $)^{1}$. This sample was also analyzed for elemental composition including noble metals. These analyses along with the WAPS analyses will help define the composition of the sludge currently in Tank 40 which is currently being fed to DWPF and will become part of Sludge Batch 5 (SB5).

SRNL analyses on SB4 were requested by DWPF via Technical Task Request (TTR) HLWDWPF-TTR-2005-0034 ${ }^{2}$. The sample preparation work is governed by Task Technical and Quality Assurance Plan (TTQAP) ${ }^{3}$, and analyses were controlled by an Analytical Study Plan ${ }^{4}$.

One 3-L sample of Tank 40 was pulled on October 10, 2007 following slurry operations. Four slurry pumps were started on October 10 and stopped at 11:22 am following eight hours of operation. The general protocol is for all four slurry pumps to run for eight hours before a DWPF transfer and to be kept running during the transfer, but due to the need to pull a sample, the pumps had to be shut down. The tank level was 128.6 inches after the pumps were secured and when the sample was pulled. The sample was sent to SRNL on October 11, 2007. 
WSRC-STI-2007-00674

Revision 0

This page intentionally left blank. 


\subsection{APPROACH AND RESULTS}

\subsection{Analytical Methods}

At the Savannah River National Laboratory (SRNL) the 3-L Tank 40 SB4 sample was transferred from the shipping container into a 4-L vessel and solids allowed to settle overnight. Supernate was then siphoned off and circulated through the shipping container to complete the transfer of the sample. Following thorough mixing of the 3-L sample, a $280 \mathrm{~g}$ sub-sample was removed. This sub-sample was then utilized for all subsequent analytical samples.

Eight separate aliquots of the slurry were digested, four with $\mathrm{HNO}_{3} / \mathrm{HCl}$ (aqua regia ${ }^{5}$ ) in sealed Teflon ${ }^{\circledR}$ vessels and four in $\mathrm{Na}_{2} \mathrm{O}_{2}$ (alkali or peroxide fusion ${ }^{6}$ ) using $\mathrm{Zr}$ crucibles. Due to the use of $\mathrm{Zr}$ crucibles and $\mathrm{Na}$ in the peroxide fusions, $\mathrm{Na}$ and $\mathrm{Zr}$ cannot be determined from this preparation. Additionally, other alkali metals, such as $\mathrm{Li}$ and $\mathrm{K}$ that may be contaminants in the $\mathrm{Na}_{2} \mathrm{O}_{2}$ are not determined from this preparation. Three Analytical Reference Glass $-1^{7}$ (ARG-1) standards were digested along with a blank for each preparation. The ARG-1 glass allows for an assessment of the completeness of each digestion. Each aqua regia digestion and blank was diluted to $1: 100 \mathrm{~mL}$ with deionized water and submitted to Analytical Development (AD) for inductively coupled plasma - atomic emission spectroscopy (ICP-AES) analysis, inductively coupled plasma - mass spectrometry (ICP-MS) analysis of masses 81-209 and 230-252, and cold vapor atomic absorption (CV-AA) analysis for $\mathrm{Hg}$. Equivalent dilutions of the peroxide fusion digestions and blank were submitted to AD for ICP-AES analysis.

Tank 40 SB4 supernate was collected from a mixed slurry sample in the SRNL Shielded Cells and submitted to AD for ICP-AES and ICP-MS. Weighted dilutions of slurry were submitted for ion chromatography (IC), total inorganic carbon/total organic carbon (TIC/TOC), and total base analyses.

A sample of Tank 40 SB4 decant was collected by carefully removing the supernate phase from a settled sample. This decant was not filtered prior to performing a warm nitric acid digestion of the material (warm acid strike ${ }^{8}$ ) in order to measure the Si content by ICP-AES. Three Si standards, a blank, and a matrix standard were prepared and submitted along with the Tank 40 samples.

\subsection{Results}

Table 2-1 presents the measured SB4 density and weight percent solids data ${ }^{9}$ collected for the final SB4 WAPS sample taken in October 2007. Table 2-1 also contains data from the DWPF Sludge Receipt and Adjustment Tank (SRAT) receipt data for Batch \#416 as a comparison. Batch \#416 was selected because this is the first DWPF batch received from Tank 40 following the Tank 40 sampling. The wt \% total solids for the Tank 40 - WAPS sample are lower than seen for Batch \#416. The higher total solids observed for the DWPF SRAT receipt batch probably reflect the impacts of the SRAT heel. The SRAT heel contributes approximately $13-$ $19 \%$ of the volume of slurry in the SRAT vessel and can have total solids ranging from $24-27$ wt \%. Calcine factors were also calculated by taking the ratio of the weight percent calcined solids and the weight percent total solids. The Tank 40 - WAPS Sample has a value of 0.75 grams of calcined solids per gram of dried solids. 
WSRC-STI-2007-00674

Revision 0

Table 2-1. Weight Percent Solids and Density for Tank 40 SB4 Samples and DWPF SRAT Receipt Batch 416 [Number of Samples Included in Average]

\begin{tabular}{ccc}
\hline Property & $\begin{array}{c}\text { Tank 40 - WAPS } \\
\text { (Std. Dev., \% RSD) }\end{array}$ & $\begin{array}{c}\text { DWPF SRAT } \\
\text { Receipt for } \\
\text { Batch 416 }^{\mathbf{a}}\end{array}$ \\
\hline Slurry Density & $1.084[4]$ & 1.135 \\
Supernate Density & $(0.008,0.7)$ & NA \\
& $1.031[4]$ & \\
Wt \% Total Solids & $(0.005,0.5)$ & 17.25 \\
& $14.44[4]$ & NA \\
Wt \% Calcined & $(0.08,0.6)$ & NA \\
Solids & $10.77[4]$ & \\
Wt \% Dissolved & $(0.09,0.8)$ & NA \\
Solids & $4.29[4]$ & \\
Wt \% Insoluble & $(0.04,0.9)$ & NA \\
Solids & 10.60 & \\
Wt \% Soluble \\
Solids
\end{tabular}

As shown in Table 2-2, there is generally reasonable agreement between the anion results for the Tank 40 WAPS sample and the available DWPF SRAT Receipt data for Batch \#416. The Al, B, $\mathrm{Ca}, \mathrm{Cr}, \mathrm{K}, \mathrm{Mo}, \mathrm{Na}$, and $\mathrm{S}$ values were calculated from the ICP-AES data for the supernate. The $\mathrm{U}$ value was determined from the ICP-MS supernate data. Other supernate elements measured were below the ICP-AES detection limits. The DWPF SRAT nitrite ion concentration would be expected to be reduced relative to the incoming sludge since the heel in the SRAT is greatly reduced in nitrite ion. Similarly, the SRAT formate and nitrate ion concentration would be expected to be elevated relative to the sludge since the heel in the SRAT is greatly increased in these anions. The supernate sulfur result given is calculated from total sulfur detected in the supernate by ICP-AES and is slightly higher than the sulfate value determined by IC, though likely within the uncertainty of the two measurements. The agreement with the DWPF value for sulfate is good. 
Table 2-2. Supernate Analyses for Tank 40 SB4 Samples [Number of Samples Included in Average] (Molar or moles/L supernate)

\begin{tabular}{|c|c|c|c|}
\hline Analyte & $\begin{array}{l}\text { Tank } 40 \text { - WAPS } \\
\text { (Std. Dev., \%RSD) }\end{array}$ & Method & $\begin{array}{c}\text { SRAT Receipt for } \\
\text { Batch } 416\end{array}$ \\
\hline $\mathrm{NO}_{3}^{-}$ & $\begin{array}{c}0.130[4] \\
(0.001,0.6)\end{array}$ & IC & $0.161[4]$ \\
\hline $\mathrm{NO}_{2}^{-}$ & $\begin{array}{c}0.289[4] \\
(0.003,1.1)\end{array}$ & IC & $0.248[4]$ \\
\hline $\mathrm{SO}_{4}{ }^{2-}$ & $\begin{array}{c}0.0144[4] \\
(0.0001,0.6)\end{array}$ & IC & $0.0164[4]$ \\
\hline $\mathrm{Br}^{-}$ & $<0.0072$ & IC & NA \\
\hline $\mathrm{Cl}^{-}$ & $<0.016$ & IC & NA \\
\hline $\mathrm{CHO}_{2}^{-}$ & $<0.013$ & IC & $0.158[4]$ \\
\hline $\mathrm{C}_{2} \mathrm{O}_{4}{ }^{2-}$ & $<0.0065$ & IC & NA \\
\hline $\mathrm{F}^{-}$ & $<0.030$ & IC & NA \\
\hline $\mathrm{Al}$ & $\begin{array}{c}0.00824[4] \\
(0.00011,1.3)\end{array}$ & ICP-AES & NA \\
\hline B & $\begin{array}{c}0.000615[4] \\
(0.000007,1.2)\end{array}$ & ICP-AES & NA \\
\hline $\mathrm{Ca}$ & $\begin{array}{c}0.0000556[4] \\
(0.0000023,4.1)\end{array}$ & ICP-AES & NA \\
\hline $\mathrm{Cr}$ & $\begin{array}{c}0.000470[4] \\
(0.000034,7.2)\end{array}$ & ICP-AES & NA \\
\hline $\mathrm{K}$ & $\begin{array}{c}0.00127[4] \\
(0.00001,1.1)\end{array}$ & ICP-AES & NA \\
\hline Mo & $\begin{array}{c}0.0000104[4] \\
(0.0000002,2.0)\end{array}$ & ICP-AES & NA \\
\hline $\mathrm{Na}$ & $\begin{array}{c}0.650[4] \\
(0.022,3.4)\end{array}$ & ICP-AES & NA \\
\hline$S$ & $\begin{array}{c}0.0161[4] \\
(0.0002,1.0)\end{array}$ & ICP-AES & NA \\
\hline $\mathrm{U}$ & $\begin{array}{c}0.00014[4] \\
(0.00001,4.5)\end{array}$ & ICP-MS & NA \\
\hline
\end{tabular}

Table 2-3 provides the elemental concentrations determined for the Tank 40 decant (unfiltered) as compared with the $0.45 \mu \mathrm{m}$ filtered material shown in Table 2-2. 
Table 2-3. Elemental Composition of Tank 40 SB4 Decant Samples [Number of Samples Included in Average] (Molar or moles/L supernate)

\begin{tabular}{cc}
\hline Analyte & $\begin{array}{c}\text { Tank 40 - WAPS } \\
\text { (Std. Dev., \% RSD) }\end{array}$ \\
\hline \multirow{2}{*}{$\mathrm{Al}$} & $0.00810[4]$ \\
& $(0.00005,0.7)$ \\
$\mathrm{B}$ & $(0.000762[4]$ \\
& $0.000009,1.1)$ \\
$\mathrm{Cr}$ & $(0.000008,1.6)$ \\
& $0.000237[4]$ \\
$\mathrm{Fe}$ & $(0.000081,34)$ \\
& $0.00121[4]$ \\
$\mathrm{K}$ & $(0.00005,4.1)$ \\
& $0.0000599[4]$ \\
$\mathrm{Mg}$ & $(0.0000026,4.4)$ \\
& $0.0000448[4]$ \\
$\mathrm{Mn}$ & $(0.0000010,2.2)$ \\
& $0.641[4]$ \\
$\mathrm{Na}$ & $(0.00366,0.6)$ \\
& $0.0164[4]$ \\
$\mathrm{S}$ & $(0.0002,1.3)$ \\
$\mathrm{Si}$ & $<0.000565$ \\
\hline
\end{tabular}

Table 2-4 provides the total carbon (TC) and total inorganic carbon (TIC) measured for the SB4 WAPS sample. The TIC value measured for SRAT Batch \#416 is $25 \%$ higher, but no TC value is available for comparison.

Table 2-4. Carbon Analysis for Tank 40 SB4 Samples [Number of Samples Included in Average] (mg C/kg slurry)

\begin{tabular}{ccc}
\hline Analyte & $\begin{array}{c}\text { Tank 40 - WAPS } \\
\text { (Std. Dev., \%RSD) }\end{array}$ & $\begin{array}{c}\text { SRAT Receipt for } \\
\text { Batch 416 }\end{array}$ \\
\hline Total Inorganic & $897[4]$ & $1126[4]$ \\
Carbon & $(29,3.2)$ & \\
Total Carbon & $1367[3]$ & NA \\
& $(52,3.8)$ & \\
\hline $\mathrm{NA} \equiv$ Not measured &
\end{tabular}

Table 2-5 provides the base measurements made on the SB4 WAPS sample. Total base represents the value determined from an inflection endpoint titration to $\mathrm{pH} 7$. Free $\mathrm{OH}^{-}$ represents the value determined after precipitation of carbonate with $\mathrm{BaCl}_{2}$ and titration to the first inflection endpoint between $\mathrm{pH} 11$ and 8. Further titration of this treated sample to $\mathrm{pH} 7$ yields the value for other base. 
WSRC-STI-2007-00674

Revision 0

Table 2-5. Base Analysis for Tank 40 SB4 Samples [Number of Samples

Included in Average] (mol/kg slurry)

\begin{tabular}{ccc}
\hline Analyte & $\begin{array}{c}\text { Tank 40 - WAPS } \\
\text { (Std. Dev., \%RSD) }\end{array}$ & $\begin{array}{c}\text { SRAT Receipt for } \\
\text { Batch 416 }\end{array}$ \\
\hline Total Base & $0.121[4]$ & 0.113 \\
Free $\mathrm{OH}^{-}$ & $(0.008,6.4)$ & \\
& $0.0392[4]$ & NA \\
Other Base & $(0.0026,6.7)$ & \\
& $0.0248[2]$ & NA \\
\hline NA $\equiv$ Not measured & $(0.0015,5.9)$ & \\
\end{tabular}

$\mathrm{NA} \equiv$ Not measured

The elemental concentrations determined by ICP-AES, ICP-MS, and CV-AA analyses are presented in Table 2-6. For the Tank 40 - WAPS sample, results from both digestions have been combined where appropriate. In the case of $\mathrm{Sb}$, only the peroxide fusion preparation was measured for this element. Also, due to the use of $\mathrm{Zr}$ crucibles and $\mathrm{Na}_{2} \mathrm{O}_{2}$ in the alkali fusions, $\mathrm{Zr}$ and $\mathrm{Na}$ values, as well as other alkali metals, were determined from the aqua regia digestion. In the case of $\mathrm{B}, \mathrm{Be}, \mathrm{Ce}, \mathrm{Mo}, \mathrm{Sn}, \mathrm{V}$, and $\mathrm{Zn}$, both preparations yielded values below the detection limits, hence Ce was determined by ICP-MS and the lowest detection limit value was selected for the remaining elements. Peroxide fusion data was used to report values for $\mathrm{Al}$ and Si for the Tank 40 - WAPS sample since the aqua regia preparation fails to dissolve all forms of these elements. ICP-MS analysis of the aqua regia digestion was also used to determine the concentrations of Cd, Gd, La and U. 
Table 2-6. Elemental Concentrations in Tank 40 SB4 Samples in Wt \% of Total Solids [Number of Samples Included in Average] (Std. Dev., \%RSD)

\begin{tabular}{|c|c|c|c|}
\hline Element & Tank 40 - WAPS & Element & Tank 40 - WAPS \\
\hline $\mathrm{Al}$ & $\begin{array}{c}9.52[4] \\
(0.04,0.4)\end{array}$ & Mo & $<0.014$ \\
\hline B & $<0.011$ & $\mathrm{Na}$ & $\begin{array}{c}11.0[4] \\
(0.07,0.6)\end{array}$ \\
\hline $\mathrm{Ba}$ & $\begin{array}{c}0.0479[8] \\
(0.0005,1.1)\end{array}$ & $\mathrm{Ni}$ & $\begin{array}{c}0.894[8] \\
(0.017,1.9)\end{array}$ \\
\hline $\mathrm{Ca}$ & $\begin{array}{c}1.41[8] \\
(0.09,6.6)\end{array}$ & $\mathrm{P}$ & $\begin{array}{c}0.297[4] \\
(0.022,7.5)\end{array}$ \\
\hline Cd & $\begin{array}{c}0.194[4] \ddagger \\
(0.007,3.4)\end{array}$ & $\mathrm{Pb}$ & $\begin{array}{c}0.0417[3] \\
(0.0046,11)\end{array}$ \\
\hline Ce & $\begin{array}{c}0.0401[4] \ddagger \\
(0.0008,2.0)\end{array}$ & S & $\begin{array}{c}0.332[4] \\
(0.016,4.7)\end{array}$ \\
\hline $\mathrm{Cr}$ & $\begin{array}{c}0.0767[4] \\
(0.0004,0.5)\end{array}$ & $\mathrm{Sb}$ & $<0.069$ \\
\hline $\mathrm{Cu}$ & $\begin{array}{c}0.0331[4] \\
(0.0006,1.8)\end{array}$ & $\mathrm{Si}$ & $\begin{array}{c}0.899[4] \\
(0.018,2.0)\end{array}$ \\
\hline $\mathrm{Fe}$ & $\begin{array}{c}14.3[8] \\
(0.2,1.6)\end{array}$ & Sn & $<0.20$ \\
\hline Gd & $\begin{array}{c}0.0147[4] \ddagger \\
(0.0009,5.8)\end{array}$ & $\mathrm{Sr}$ & $\begin{array}{c}0.0235[8] \\
(0.0011,4.6)\end{array}$ \\
\hline $\mathrm{Hg}$ & $\begin{array}{c}0.814 \wedge[4] \\
(0.028,3.4)\end{array}$ & $\mathrm{Ti}$ & $\begin{array}{c}0.0166[4] \\
(0.0001,0.9)\end{array}$ \\
\hline $\mathrm{La}$ & $\begin{array}{c}0.0300 \ddagger[4] \\
(0.0007,2.3)\end{array}$ & $\mathrm{U}$ & $\begin{array}{l}5.29+\neq[4] \\
(0.17,3.1)\end{array}$ \\
\hline $\mathrm{Li}$ & $\begin{array}{c}0.0221[4] \\
(0.0005,2.3)\end{array}$ & V & $<0.0055$ \\
\hline $\mathrm{Mg}$ & $\begin{array}{c}1.17[8] \\
(0.05,4.0)\end{array}$ & $\mathrm{Zn}$ & $<0.045$ \\
\hline $\mathrm{Mn}$ & $\begin{array}{c}3.18[8] \\
(0.04,1.2)\end{array}$ & $\mathrm{Zr}$ & $\begin{array}{c}0.04[4] \\
(0.02,54)\end{array}$ \\
\hline
\end{tabular}


The fission product noble metal and silver concentrations are given in Table 2-7. The values were calculated from ICP-MS data using a spreadsheet developed by Ned Bibler (SRNL). This spreadsheet uses the fission yield for each isotope to account for the mass contribution from isotopes in the tank that could not be measured because isotopes of natural Cd interfere at this mass. An example of this is the measurement at mass 110, which is comprised of Pd-110 and Cd-110. For comparison purposes, data for the SB4 Qualification Sample and the estimated concentrations for Shielded Cells SRAT Cycle 1 (SC-1) Blend Sample (70\% Tank 40 (SB3) / 30\% Tank 51 (SB4 Qualification Sample)) are also given ${ }^{10}$. The values for each noble metal are in reasonably good agreement considering the low concentrations being measured to calculate them. Additionally, the SB4 Qualification Sample results do not include an estimate for the impact on the noble metals concentrations as a result of the SB3 heel in Tank 40. The calculated SC-1 Blend Sample values did take into consideration the impact of this heel and show excellent agreement with the measured values.

Table 2-7. Noble Metal Fission Products and Silver Concentrations in Tank 40 SB4 WAPS and Qualification Samples in Wt \% of Total Solids

\begin{tabular}{|c|c|c|c|}
\hline Element & Tank 40 - WAPS & $\begin{array}{c}\text { SB4 Qualification } \\
\text { Sample }^{\mathbf{1 0}}\end{array}$ & $\begin{array}{l}\text { SC-1 Blend } \\
\text { Sample }^{10 *}\end{array}$ \\
\hline $\operatorname{Ag}(-107,-109)$ & 0.00987 & 0.00292 & 0.00950 \\
\hline $\operatorname{Pd}(-105,-106,-107,-108,-110)$ & 0.00124 & 0.000857 & 0.00132 \\
\hline Rh (-103) & 0.00840 & 0.0104 & 0.00824 \\
\hline Ru (-101, -102, -104) & 0.0313 & 0.0427 & 0.0348 \\
\hline
\end{tabular}


WSRC-STI-2007-00674

Revision 0

This page intentionally left blank. 


\subsection{DISCUSSION}

\subsection{Carbonate}

Subtracting the free $\mathrm{OH}^{-}$and other base values from the total base measurement should yield the carbonate contribution to the base equivalents. The carbonate contribution determined from the titration measurements is $0.057 \mathrm{~mol}$ carbonate $/ \mathrm{kg}$ slurry. This compares to a carbonate concentration via the TIC measurement of $0.075 \mathrm{~mol}$ carbonate $/ \mathrm{kg}$ slurry. The agreement is good considering the large uncertainty in determining carbonate via titration.

\subsection{Warm Acid Strike for Soluble Silica}

The warm acid strike method $^{8}$ was utilized to measure the concentration of Si in a Tank 40 decant. The amount of Si measured was below the detection limit and below the lowest standard value of $0.5 \mathrm{ppm} \mathrm{Si}$. There was excellent agreement between the values for the elements $\mathrm{Al}, \mathrm{Cr}$, $\mathrm{K}, \mathrm{Na}$, and $\mathrm{S}$ which were detected in both the warm acid strike treated decant and the filtered supernate (Table 2-2), indicating there is no significant contribution to the concentrations of these elements from suspended fine particles that may be present in the decant.

\subsection{Sulfur}

The conversion of the total supernate sulfur values, as shown in Table 2-3, from molar to wt\% of total solids, yields $0.310 \mathrm{wt} \% \mathrm{~S}$ for the Tank 40 - WAPS sample. Comparing this value with the total slurry sulfur value in Table 2-6 indicates that 93\% of the sulfur in the WAPS sample is soluble. Within the uncertainty of the measurements, it is reasonable to assume that virtually all of the sulfur remains as soluble species in the sludge.

\subsection{Elemental Ratios}

A comparison of the elemental ratios of the major insoluble solids using data from Table 2-6 is given in Table 3-1. SRAT Product Batch \#416 data is from DWPF and was used to calculate the ratios of $\mathrm{Fe}$ to $\mathrm{Al}, \mathrm{Ca}, \mathrm{Mn}$, and $\mathrm{U}$ since receipt data on these elements is not available. These ratios should remain constant through batch processing unless an addition of material containing one or more elements of interest is made. Generally, the agreement between the Tank 40 WAPS sample and the DWPF Batch \#416 data is good, differing by less than 10\% except for U, which is within the analytical uncertainty of the measured data. The U value reported for DWPF SRAT Batch \#416 is from ICP-AES rather than ICP-MS, and it is likely biased low. Using the U value determined by ICP-AES for the WAPS sample (5.01 wt\% TS) yields a U/Fe ratio of 0.35 which is $18 \%$ higher than that observed in DWPF. Generally, the U values determined in DWPF have been lower than those determined at SRNL.

Table 3-1. Comparison of Elemental Ratios of Major Insoluble Elements in Tank 40 SB4 Sample with DWPF Batch 416 SRAT Product Data

\begin{tabular}{cccc}
\hline Element Ratio & $\begin{array}{c}\text { Tank 40 }- \\
\text { WAPS }\end{array}$ & $\begin{array}{c}\text { DWPF SRAT } \\
\text { Product } \\
\text { Batch 416 }\end{array}$ & $\begin{array}{c}\text { \% Difference } \\
\text { WAPS - } \\
\text { Batch 416 }\end{array}$ \\
\hline $\mathrm{Al} / \mathrm{Fe}$ & 0.67 & 0.67 & 0 \\
$\mathrm{Ca} / \mathrm{Fe}$ & 0.099 & 0.091 & 9 \\
$\mathrm{Mn} / \mathrm{Fe}$ & 0.22 & 0.22 & 0 \\
$\mathrm{U} / \mathrm{Fe}$ & 0.37 & 0.30 & 23 \\
\hline
\end{tabular}




\subsection{Noble Metal Ratios}

A comparison of the fission yield ratios for $\mathrm{Ru}: \mathrm{Rh}, \mathrm{Ru}: \mathrm{Pd}$, and $\mathrm{Ru}: \mathrm{Ag}$ with those measured for the Tank 40 - WAPS sample is provided in Table 3-2. The SB4 Qualification Sample results and estimated values for the SC-1 Blend Sample are provided for comparison. The ratios are based upon Ru due to its relatively high concentration in the sludge as compared with the other noble metals. The $\mathrm{Ru}: \mathrm{Rh}$ ratio agrees reasonably well for all three samples, while the $\mathrm{Ru}$ :Ag ratios differ significantly from the fission yield ratios. This lack of agreement for the Ag ratios is not unexpected since the majority of the Ag is natural Ag originating from Ag saddles used in the dissolvers to scavenge radioactive iodine, while the noble metals are fission products of U-235. Consequently by the relative concentration of $\mathrm{Ag}$, the fission products are not expected to be in proportion to their fission yields. The Ru:Pd ratios agree for the WAPS and the estimated SC-1 Blend samples, but not with that predicted by the fission yield. A possible explanation for this is that a portion of the Pd is soluble and hence has fractioned off into the salt waste, thus increasing the ratio of $\mathrm{Ru}$ to $\mathrm{Pd}$ in the sludge waste.

Table 3-2. Fission Yield Ratios and Measured Noble Metal Ratios in Various SB4 Samples

\begin{tabular}{ccccc}
\hline Ratio & Fission Yield & $\begin{array}{c}\text { Tank 40 - } \\
\text { WAPS }\end{array}$ & $\begin{array}{c}\text { SB4 Qualification } \\
\text { Sample }^{\mathbf{1 0}}\end{array}$ & $\begin{array}{c}\text { SC-1 Blend } \\
\text { Sample }^{\mathbf{1 0}}\end{array}$ \\
\hline Ru:Rh & 3.7 & 3.7 & 4.1 & 4.2 \\
Ru:Pd & 6.9 & 25 & 50 & 26 \\
Ru:Ag & 342 & 3.2 & 15 & 3.7 \\
\hline${ }^{10}$ Pareizs, J. M., Bannochie, C. J., Barnes, M. J., Bibler, N. E., Click, D. R., Hansen, E. K., Lambert, D. P., Stone, M. E. Demonstration of \\
the DWPF Flowsheet in the SRNL Shielded Cells in Support of Sludge Batch 4 Qualification, WSRC-STI-2007-00053, Savannah River \\
Site, Aiken, SC 29808 (2007).
\end{tabular}




\subsection{CONCLUSIONS}

- The elemental composition of this sample and the analyses conducted here are reasonable and consistent with DWPF batch data measurements.

- There was no measurable Si in samples of Tank 40 decant.

- Ag and the $\mathrm{Ru}, \mathrm{Rh}$, and Pd noble metal concentrations agree well with the estimate used for the SB4 70/30 blend of SB3 and Tank 51 performed in the SRNL Shielded Cells. 
WSRC-STI-2007-00674

Revision 0

This page intentionally left blank. 


\subsection{REFERENCES}

${ }^{1}$ Office of Environmental Restoration and Waste Management, Waste Acceptance Product Specifications for Vitrified High-Level Waste Forms, US DOE Document DOE/EM-0093, Rev. 2, (12/96).

2 Davis, B. A. Sludge Batch 4 SRNL Shielded Cells Testing, HLW-DWPF-TTR-2005-0034, Rev. 0, Savannah River Site, Aiken, SC 29808 (2006).

${ }^{3}$ Bannochie, C. J., Pareizs, J. M. Qualification of DWPF Sludge Batch 4 (Macrobatch 5) in the SRNL Shielded Cells: Task Technical and Quality Assurance Plan, WSRC-RP-2006-00310, Rev. 1, Savannah River Site, Aiken, SC 29808 (2006).

${ }^{4}$ Bannochie, C. J., Pareizs, J. M. Qualification of DWPF Sludge Batch 4 (Macrobatch 5) in the SRNL Shielded Cells: Analytical Study Plan, WSRC-RP-2006-00458, Rev. 1, Savannah River Site, Aiken, SC 29808 (2006).

${ }^{5}$ Coleman, C. J. Aqua Regia Dissolution of Sludge for Elemental Analysis, Manual L16.1, Procedure ADS-2226, Rev. 6, Savannah River Site, Aiken, SC 29808 (2003).

${ }^{6}$ Coleman, C. J. Alkali Fusion Dissolutions of Sludge and Glass for Elemental and Anion Analysis, Manual L16.1, ADS-2502, Rev. 5, Savannah River Site, Aiken, SC 29808 (2002).

${ }^{7}$ Smith, G. L. Characterization of Analytical Reference Glass - 1 (ARG-1), PNL-8992, Pacific Northwest (National) Laboratory, Richland, WA (1993).

${ }^{8}$ Coleman, C. J. Sample Preparation Procedure for Warm Acid Strike, Acid Dilution, and Water Dilution, Manual L16.1, ADS-2285, Rev. 0, Savannah River Site, Aiken, SC (2003).

${ }^{9}$ Marek, J. C., Correction Factor for Soluble and Insoluble Solids, SRTC-PTD-92-0040, Savannah River Site, Aiken, SC 29808 (1992).

${ }^{10}$ Pareizs, J. M., Bannochie, C. J., Barnes, M. J., Bibler, N. E., Click, D. R., Hansen, E. K., Lambert, D. P., Stone, M. E. Demonstration of the DWPF Flowsheet in the SRNL Shielded Cells in Support of Sludge Batch 4 Qualification, WSRC-STI-2007-00053, Savannah River Site, Aiken, SC 29808 (2007). 
WSRC-STI-2007-00674

Revision 0

This page intentionally left blank. 


\subsection{ACKNOWLEDGEMENTS}

The author would like to acknowledge the support of the SRNL Shielded Cells technicians and supervision. Additionally, we would like to thank Ned Bibler (PS\&E) for useful discussions and guidance in the calculation of noble metal concentrations. 


\section{Distribution:}

J. E. Marra, 773-A

R. E. Edwards, 773-A

D. A. Crowley, 999-W

C. C. Herman, 999-W

A. B. Barnes, 999-W

D. B. Burns, 786-5A

N. E. Bibler, 773-A

C. M. Jantzen, 773-A

J. M. Pareizs, 773-A

D. K. Peeler, 999-W

D. C. Koopman, 999-W

M. E. Stone, 999-W

D. P. Lambert, 999-W

T. B. Edwards, 999-W

J. E. Occhipinti, 704-S

J. F. Iaukea, 704-30S

J. W. Ray, 704-S

R. T. McNew, 704-27S

B. A. Davis, 704-27S

B. H. Culberston, 703-27S

T. L. Fellinger, 704-26S

H. H. Elder, 704-26S

H. B. Shah, 766-H

J. M. Gillam, 766-H

B. A. Hamm, 766-H

D. J. Martin, 703-H 